\title{
2D and 3D Supramolecular Structures of trans- and cis-Octahedral Coordination Compounds of Ethyl-5-methyl-4-imidazolecarboxylate with Transition Metal Ions
}

\author{
Víctor Adán Barrera-Guzmán, Raúl Ramírez-Trejo, Edgar Omar Rodríguez-Hernández, and Noráh Barba- \\ Behrens*
}

Departamento de Química Inorgánica, Facultad de Química, Universidad Nacional Autónoma de México, Ciudad Universitaria, México, D.F., 04510, México. Tel/fax: +52-55-622-3810, norah@unam.mx

Dedicated to Estela Sánchez Quintanar, friend and colleague, in recognition of her contribution to the biochemistry of maize

Received February 1, 2011; accepted June 6, 2011

\begin{abstract}
Ethyl-5-methyl-4-imidazolecarboxylate (emizco) is an important intermediate in the synthesis of pharmacological active compounds. In this work, there were synthetized and characterized the following coordination compounds with emizco: trans-[Co(emizco $\left.)_{2}\left(\mathrm{H}_{2} \mathrm{O}\right)_{2}\right]\left(\mathrm{NO}_{3}\right)_{2} \mathbf{1}$, trans- $\left[\mathrm{Ni}(\mathrm{emizco})_{2}\left(\mathrm{H}_{2} \mathrm{O}\right)_{2}\right]\left(\mathrm{NO}_{3}\right)_{2}$ 2, trans- $\left[\mathrm{Cd}(\mathrm{emizco})_{2}\left(\mathrm{H}_{2} \mathrm{O}\right)_{2}\right]\left(\mathrm{NO}_{3}\right)_{2}(\mathbf{3})$ and cis- $\left[\mathrm{Cd}(\mathrm{emizco})_{2} \mathrm{Br}_{2}\right](\mathbf{4})$. $2 \mathrm{D}$ or $3 \mathrm{D}$ supramolecular arrangements were stabilized. All nitrate trans octahedral compounds stabilized a 3D supramolecular arrangement via hydrogen bonding, throughout the nitrate anions, the ligand and the coordinated water molecules; the cis-octahedral halide complex formed a 2D pleated sheet arrangement, by intermolecular $\pi$ stacking and halide-hydrogen bonding.

Key words: Emizco, cobalt(II), nickel(II), cadmium(II), coordination compounds, supramoleular arrangements.
\end{abstract}

\section{Introduction}

The interaction of imidazole derivatives with metal ions is a subject of continuous interest. It is well known that a number of imidazole derivatives have biological activity, e.g. presenting pharmaceutical, antibacterial or fungicidal properties [1-3], among others. Within this class of compounds, nitroimidazoles have been used in the treatment of tropical diseases, in protozoal, anaerobic bacteria and the eradication of Helicobacter pylori infections [4-9], as in medical creams for treating acne, seborrheic dermatitis, rosacea and folliculitis [10]. Their biological activity as radiosensitizers, or as hypoxic cytotoxins has been studied [11-19]. Furthermore, these molecules may easily coordinate to transition metal ions, giving stable coordination compounds. The nitro group adjacent to an imidazolic nitrogen may occupy a coordination site, stabilizing chelate metal complexes, while the hydroxyethyl and nitro groups act as supramolecular synthons, with the option to generate hydrogen-bonded networks of different dimensions. The number, orientation and type of hydrogen bonding drive the formation of mono and two dimensional networks. The contribution of metal ions in metronidazole coordination compounds is shown in the stabilization of different aggregate structures, as we have informed [20]. Ethyl 5-methyl-4-imidazolecarboxylate (hereafter abbreviated emizco), is used as an intermediate in the synthesis of a variety of imidazolic compounds with pharmacological proper-
Resumen. El etil 5-metil-4-imidazolcarboxilato (emizco) es un intermediario importante en la síntesis de compuestos con actividad farmacológica. En el presente trabajo se sintetizaron y caracterizaron los siguientes compuesto de coordinación con emizco: trans $-\left[\mathrm{Co}(\mathrm{emizco})_{2}\left(\mathrm{H}_{2} \mathrm{O}\right)_{2}\right]\left(\mathrm{NO}_{3}\right)_{2} \mathbf{1}$, trans- $\left[\mathrm{Ni}(\mathrm{emizco})_{2}\left(\mathrm{H}_{2} \mathrm{O}\right)_{2}\right]\left(\mathrm{NO}_{3}\right)_{2}$ 2, trans- $\left[\mathrm{Cd}(\mathrm{emizco})_{2}\left(\mathrm{H}_{2} \mathrm{O}\right)_{2}\right]\left(\mathrm{NO}_{3}\right)_{2}(\mathbf{3})$ y cis- $\left[\mathrm{Cd}(\mathrm{emizco})_{2} \mathrm{Br}_{2}\right]$ (4). Estos compuestos estabilizan estructuras supramoleculares en $2 \mathrm{D}$ ó $3 \mathrm{D}$; todos los compuestos de nitrato con geometría trans octaédrica estabilizan arreglos en 3D por medio de puentes de hidrógeno entre los iones nitrato, emizco y las moléculas de $\mathrm{H}_{2} \mathrm{O}$; mientras que el compuesto de coordinación del haluro cis octaédrico tiene un arreglo en forma de hoja plegada en 2D, por medio de interacciones intermoleculares de tipo apilamiento- $\pi$ y puente de hidrógeno-haluro.

Palabras clave: Emizco, cobalto(II), niquel(II), cadmio(II), compuesto de coordinación, arreglos supramoleculares.

ties [21, 22]. Previously, we have investigated the coordination compounds of emizco with copper(II) [23], and the biological activity of its transition metal complexes on photosynthesis. They showed to be inhibitors of the photosynthetic electron flow and ATP-synthesis [24, 25]. In the copper(II) coordination compounds, the imidazole nitrogen atom and its neighbouring ester group are active sites for binding the $\mathrm{Cu}^{2+}$ atom, giving place to mono- or bi-dentate coordination modes, therefore stabilizing tetrahedral or octahedral geometries. In this paper we present the synthesis and the structural characterization of coordination compounds of emizco with cobalt(II), nickel(II) and cadmium(II) salts. This work was undertaken to contribute to a better understanding of the coordination behavior of this biologically relevant compound towards metal ions, the geometries and isomers that the metal atoms may adopt in these compounds, as the contribution of the counterion on the stabilization of 2D and 3D molecular aggregates.

\section{Results and Discussion}

When the reaction syntheses of emizco was carried out with the corresponding nitrate salts, the octahedral trans complexes: $\mathbf{1}$, $\mathbf{2}$ and 3 were obtained, while with cadmium bromide the cis compound $\mathbf{4}$ was isolated. These reactions are summarized in Scheme 1. 


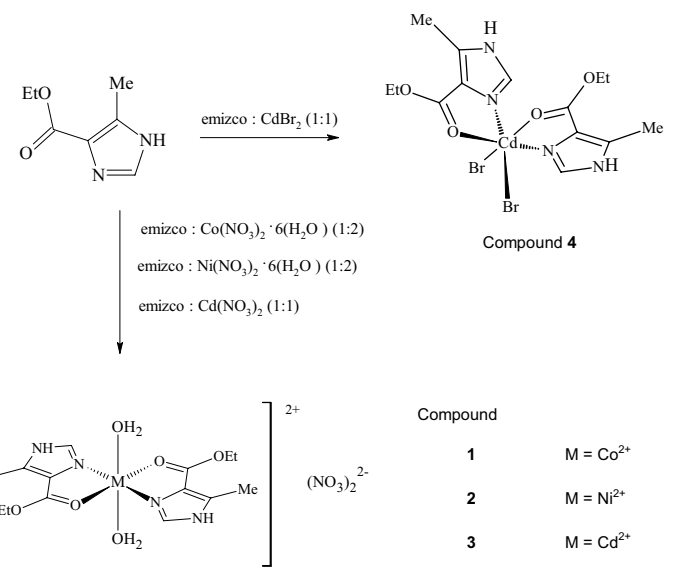

Scheme 1. Synthesis of compounds 1-4.

\section{Spectroscopic characterization}

In Table 1, spectral and magnetic data of emizco and its coordination compounds are presented. The IR spectrum of emizco showed absorption bands corresponding to the stretching modes $v(\mathrm{C}=\mathrm{O}), v_{\text {as }}(\mathrm{C}-\mathrm{O}-\mathrm{C}), v_{\mathrm{s}}(\mathrm{C}-\mathrm{O}-\mathrm{C})$ of the ester functional group at 1693,1321 and $1180 \mathrm{~cm}^{-1}$ respectively, and for the $v(\mathrm{C}=\mathrm{N})$ at $1508 \mathrm{~cm}^{-1}$. For compounds $\mathbf{1 - 4}$, the ester bands are shifted, upon coordination, with respect to the respective bands in the free ligand; the $v(\mathrm{C}=\mathrm{O})$ stretching band is shifted to lower energies $\left(1644-1678 \mathrm{~cm}^{-1}\right)$, while $v(\mathrm{C}=\mathrm{N})$ is shifted to higher energy $\left(1509-1528 \mathrm{~cm}^{-1}\right)$, indicating that the emizco ligands are coordinated to the metal ion in a bidentate mode, through the $\mathrm{C}=\mathrm{O}$ of the ester group and the imidazolic nitrogen, in agreement with their X-ray structures.

Reflectance spectrum of $\left[\mathrm{Co}(\text { emizco })_{2}\left(\mathrm{H}_{2} \mathrm{O}\right)_{2}\right]\left(\mathrm{NO}_{3}\right)_{2} \mathbf{1}$ is characteristic of a cobalt(II) in an octahedral geometry, with a band centered at $9100 \mathrm{~cm}^{-1}$ assigned as $v_{1}{ }^{4} \mathrm{~T}_{2 \mathrm{~g}}(\mathrm{~F}) \longleftarrow{ }^{4} \mathrm{~T}_{1 \mathrm{~g}}(\mathrm{~F})$, in addition to a band at $20892 \mathrm{~cm}^{-1}$ corresponding to $v_{3}{ }^{4} \mathrm{~T}_{1 \mathrm{~g}}(\mathrm{P}) \leftarrow$ ${ }^{4} \mathrm{~T}_{1 \mathrm{~g}}(\mathrm{~F})$ [27]. The $\left[\mathrm{Ni}(\text { emizco })_{2}\left(\mathrm{H}_{2} \mathrm{O}\right)_{2}\right]\left(\mathrm{NO}_{3}\right)_{2} 2$ compound exhibits three bands at $9803 \mathrm{~cm}^{-1}, v_{1}={ }^{3} \mathrm{~T}_{2 \mathrm{~g}}(\mathrm{~F}) \leftarrow^{3} \mathrm{~A}_{2 \mathrm{~g}}(\mathrm{~F}), 15852$ $\mathrm{cm}^{-1}, v_{2}={ }^{3} \mathrm{~T}_{1 \mathrm{~g}}(\mathrm{~F}) \leftarrow{ }^{3} \mathrm{~A}_{2 \mathrm{~g}}(\mathrm{~F})$, and $25809 \mathrm{~cm}^{-1}, v_{3}={ }^{3} \mathrm{~T}_{1 \mathrm{~g}}(\mathrm{P}) \leftarrow$ ${ }^{3} \mathrm{~A}_{2 \mathrm{~g}}(\mathrm{~F})$. These transitions are within the expected range for a nickel(II) ion with an octahedral geometry [26]. In this compound the first transition $\left(9803 \mathrm{~cm}^{-1}\right)$ corresponds to the $10 \mathrm{Dq}$, indicative of a weak crystal field splitting.
In summary, a chelating coordination behavior of emizco towards the transition metal ions was observed in these compounds, where the metal ions adopted an octahedral geometry.

\section{Magnetic susceptibility and electrical conductivity}

For $\left[\mathrm{Co}(\text { emizco })_{2}\left(\mathrm{H}_{2} \mathrm{O}\right)_{2}\right]\left(\mathrm{NO}_{3}\right)_{2}$, an effective magnetic moment of 4.82 B.M. was observed, which is within the expected range for a high spin $\mathrm{Co}^{2+}$ ion with three unpaired electrons. The nickel(II) compound $\left[\mathrm{Ni}(\mathrm{emizco})_{2}\left(\mathrm{H}_{2} \mathrm{O}\right)_{2}\right]\left(\mathrm{NO}_{3}\right)_{2}$, presented a magnetic moment of 3.17 B.M., as expected for this metal ion in an octahedral geometry. Their molar conductivities are characteristic for 1:2 electrolytes, for the nitrate complexes 1 and 2 are within the range of $222-257 \mu \mathrm{S} / \mathrm{cm}$ (in water), and for compound 3 a conductivity of $78 \mu \mathrm{S} / \mathrm{cm}$ (in DMSO) was found.

\section{X-ray crystal structures of compounds 1-4}

Suitable crystals for X-ray diffraction studies were obtained for the coordination compounds 1-4. The nitrate complexes 13 correspond to a centrosymmetric trans-octahedral geometry (Fig. 1), and the bromide compound $\mathbf{4}$ to a cis-octahedral geometry (Fig. 2).

The stabilization of these isomers was controlled by the counterion used in the reaction synthesis. The nitrate anions favors the centrosymmetric trans-octahedral cationic complexes $\left[\mathrm{M}(\text { emizco })_{2}\left(\mathrm{H}_{2} \mathrm{O}\right)_{2}\right]\left(\mathrm{NO}_{3}\right)_{2}$, where $\mathrm{M}=\mathrm{Co}^{2+}, \mathrm{Ni}^{2+}$ and $\mathrm{Cd}^{2+}$
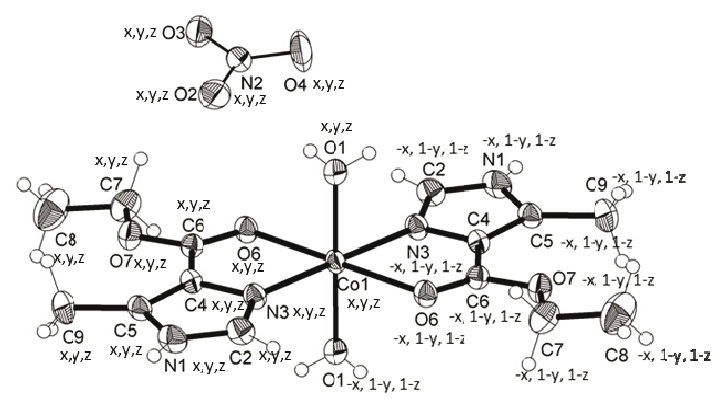

Fig. 1. Crystal structure of compound $\left[\mathrm{Co}(\text { emizco })_{2}\left(\mathrm{H}_{2} \mathrm{O}\right)_{2}\right]\left(\mathrm{NO}_{3}\right)_{2} \mathbf{1}$ with symmetry operator labels and thermal ellipsoids for non- $\mathrm{H}$ atoms at the $30 \%$ probability level.

Table 1. Spectral and magnetic data for emizco and its coordination compounds 1-4.

\begin{tabular}{|c|c|c|c|c|c|c|c|}
\hline \multirow[t]{2}{*}{ Compound } & \multirow[t]{2}{*}{$\mu_{\mathrm{eff}}^{\mathrm{a}}(\mathrm{MB})$} & \multirow[t]{2}{*}{ UV-Vis-NIR ${ }^{\mathrm{b}}\left(\mathrm{cm}^{-1}\right)$} & \multicolumn{5}{|c|}{$\mathrm{IR}^{\mathrm{c}} v_{\max } / \mathrm{cm}^{-1}$} \\
\hline & & & $v(\mathrm{C}=\mathrm{O})$ & $v(\mathrm{C}=\mathrm{N})$ & $\mathrm{v}_{\mathrm{as}}(\mathrm{COC})$ & $v_{s}(\mathrm{COC})$ & $v\left(\mathrm{NO}_{3}\right)$ \\
\hline emizco & - & - & 1693 & 1508 & 1321 & 1180 & - \\
\hline 2. trans- $\left[\mathrm{Ni}(\mathrm{emizco})_{2}\left(\mathrm{H}_{2} \mathrm{O}\right)_{2}\right]\left(\mathrm{NO}_{3}\right)_{2}$ & 3.17 & $v_{1} 9803, v_{2} 15852, v_{3} 25809$ & 1644 & 1528 & - & 1217 & 1384 \\
\hline 3. trans $-\left[\mathrm{Cd}(\mathrm{emizco})_{2}\left(\mathrm{H}_{2} \mathrm{O}\right)_{2}\right]\left(\mathrm{NO}_{3}\right)_{2}$ & - & - & 1655 & 1525 & 1335 & 1163 & 1384 \\
\hline
\end{tabular}

${ }^{\mathrm{a}} 25{ }^{\circ} \mathrm{C}$; b diffuse reflectance; centered band; ${ }^{\mathrm{c}} \mathrm{KBr}$ pellets, range $4000-600 \mathrm{~cm}^{-1}$. 


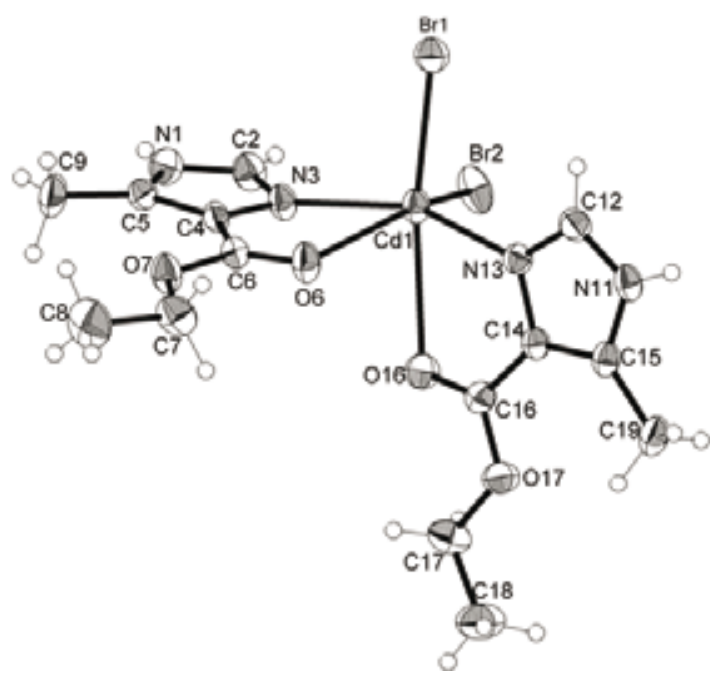

Fig. 2. Crystal structure of $\left[\mathrm{Co}(\mathrm{emizco})_{2} \mathrm{Br}_{2}\right] 4$ with thermal ellipsoids for non-H atoms at the $30 \%$ probability level.

(compounds $\mathbf{1}, \mathbf{2}$ and $\mathbf{3}$ ), whereas the bromide favor the cis geometry, $\left[\mathrm{Cd}(\mathrm{emizco})_{2} \mathrm{Br}_{2}\right] \mathbf{4}$, as it was previously observed for the copper(II) complexes trans- $\left[\mathrm{Cu}(\mathrm{emizco})_{2}\left(\mathrm{H}_{2} \mathrm{O}\right)_{2}\right]\left(\mathrm{NO}_{3}\right)_{2}$ and cis-[Cu(emizco $\left.)_{2} \mathrm{X}_{2}\right]\left(\mathrm{X}^{-}=\mathrm{Cl}, \mathrm{Br}\right)$ [27]. The stabilization of the cis or trans geometry is driven by steric factors.

In the trans-octahedral compounds, two emizco ligands are coordinated in a bidentate mode to the central metal ion, the donor atoms $\mathrm{N} 3$ and $\mathrm{O} 6$ are in equatorial positions and the axial positions are occupied by two acua ligands completing the coordination sphere. This is a common geometry for this kind of compounds [27], whereas cis-coordination is rarely observed [28]. The coordination bond distances in the trans-octahedral compounds are shown in Table 2.

For the trans compounds 1-3, $\left[\mathrm{Cd}(\mathrm{emizco})_{2}\left(\mathrm{H}_{2} \mathrm{O}\right)_{2}\right]\left(\mathrm{NO}_{3}\right)_{2}$ 3 presents the longest coordination bond lengths and the smallest chelate angle $73.22(5)^{\circ}$, whereas for the cobalt(II)

Table 2. Selected bond lengths $[\AA]$ for trans-octahedral compounds 1-3, and cis-octahedral compound 4.

\begin{tabular}{lccc}
\hline \multicolumn{1}{c}{ Compound } & M-O1 & M-N3 & M-O6 \\
\hline$\left[\mathrm{Co}(\text { emizco })_{2}\left(\mathrm{H}_{2} \mathrm{O}\right)_{2}\right]\left(\mathrm{NO}_{3}\right)_{2} \mathbf{1}$ & $2.075(2)$ & $2.088(2)$ & $2.213(1)$ \\
{$\left[\mathrm{Ni}(\mathrm{emizco})_{2}\left(\mathrm{H}_{2} \mathrm{O}\right)_{2}\right]\left(\mathrm{NO}_{3}\right)_{2} \mathbf{2}$} & $2.068(2)$ & $2.030(2)$ & $2.114(2)$ \\
{$\left[\mathrm{Cd}(\text { emizco })_{2}\left(\mathrm{H}_{2} \mathrm{O}\right)_{2}\right]\left(\mathrm{NO}_{3}\right)_{2} \mathbf{3}$} & $2.306(2)$ & $2.243(2)$ & $2.415(2)$ \\
{$\left[\mathrm{Cd}(\text { emizco })_{2} \mathrm{Br}_{2}\right] \mathbf{4}$} & - & $2.218(3)$ & $2.757(3)$ \\
\hline
\end{tabular}

and nickel(II) compounds as the coordination bond lengths get shorter, the chelate angle increases (Tables 2 and 3). Two intramolecular hydrogen bonds in the emizco ligand, $\mathrm{O} 6 \cdots \mathrm{C} 7$ $2.707 \AA$ and O7 $\cdots \mathrm{C} 93.078 \AA$, [23] are conserved in all coordination compounds, as depicted for $\left[\mathrm{Co}(\mathrm{emizco})_{2}\left(\mathrm{H}_{2} \mathrm{O}\right)_{2}\right]\left(\mathrm{NO}_{3}\right)_{2}$ 1 (Fig. 3).

A partial electronic delocalization on the chelate ring is observed, N3=C4 1.377(3) $\AA, \mathrm{C} 4-\mathrm{C} 6$ 1.450(3) $\AA, \mathrm{C} 6=\mathrm{O} 66$ 1.224(3) $\AA$. The angles O1-M-O6 and N3-M-O1 have values in the range of $87-94^{\circ}$, as expected for this geometry.

The compound cis $\left[\mathrm{Cd}(\mathrm{emizco})_{2} \mathrm{Br}_{2}\right] 4$, has the smallest chelate angles, O6-Cd1-N3 66.58(9) and O16-Cd1-N13 $68.11(9)^{\circ}$ (table 3 ), with the longest coordination bond lengths,

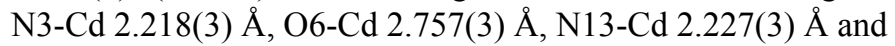
O16-Cd 2.645(3) $\AA$ (figure 4, table 2).

In the previously reported analogous copper(II) compound cis $\left[\mathrm{Cu}(\mathrm{emizco})_{2} \mathrm{Br}_{2}\right]$, the chelate angles are larger, O6-Cu1-N3 $75.91(15)^{\circ}$ and $\mathrm{O} 16-\mathrm{Cu} 1-\mathrm{N} 13 \mathrm{74.44}(14)^{\circ}$, while the coordination bond lengths are shorter when changing cadmium(II) for copper(II) [23]. The smaller chelate angles are those of the cisoctahedral compound 4, compared with the trans-octahedral 3 (Fig. 4).

\section{Supramolecular arrangements}

Trans-octahedral compounds 1-3

A 2D ribbon is build up by hydrogen bonds between the nitrate ions, the amino group of emizco ligands and the water molecules, in figures 5 and 6 these is shown for the cobalt(II)

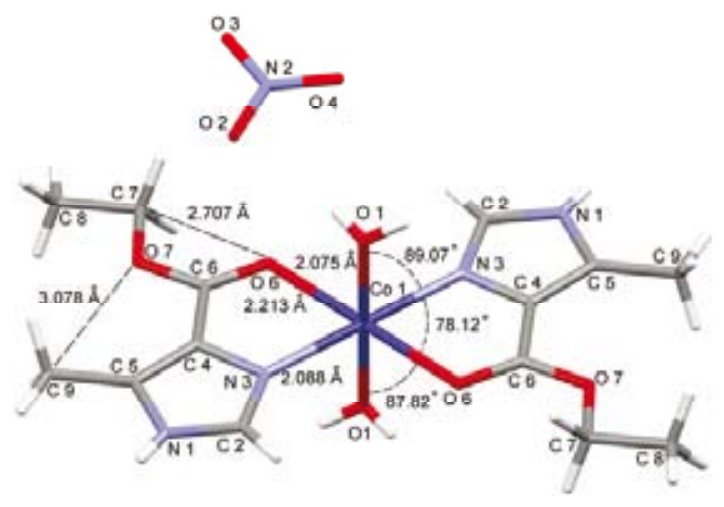

Fig. 3. Chelate angles $\left(^{\circ}\right)$, bond lengths $(\AA)$ and intramolecular hydrogen bonding in compound $\left[\mathrm{Co}(\text { emizco })_{2}\left(\mathrm{H}_{2} \mathrm{O}\right)_{2}\right]\left(\mathrm{NO}_{3}\right)_{2} \mathbf{1}$.

Table 3. Selected bond angles $\left[^{\circ}\right]$ of the trans-octahedral compounds 1-3 and cis-octahedral compound 4.

\begin{tabular}{cccc}
\hline Compound & $\mathrm{N} 3 \mathrm{x}, \mathrm{y}, \mathrm{z}-\mathrm{Mx}, \mathrm{y}, \mathrm{z}-\mathrm{O} 6 \mathrm{x}, \mathrm{y}, \mathrm{z}$ & $\mathrm{O} 1 \mathrm{x}, \mathrm{y}, \mathrm{z}-\mathrm{Mx}, \mathrm{y}, \mathrm{z}-\mathrm{N} 3 \mathrm{x}, \mathrm{y}, \mathrm{z}$ & $\mathrm{O} 6 \mathrm{x}, \mathrm{y}, \mathrm{z}-\mathrm{M}$ x,y,z-O1x,y,z \\
\hline$\left[\mathrm{Co}(\mathrm{emizco})_{2}\left(\mathrm{H}_{2} \mathrm{O}\right)_{2}\right]\left(\mathrm{NO}_{3}\right)_{2} \mathbf{1}$ & $78.12(5)$ & $89.07(7)$ & $87.81(7)$ \\
{$\left[\mathrm{Ni}(\mathrm{emizco})_{2}\left(\mathrm{H}_{2} \mathrm{O}\right)_{2}\right]\left(\mathrm{NO}_{3}\right)_{2} \mathbf{2}$} & $79.99(9)$ & $89.06(10)$ & $88.17(8)$ \\
{$\left[\mathrm{Cd}(\mathrm{emizco})_{2}\left(\mathrm{H}_{2} \mathrm{O}\right)_{2}\right]\left(\mathrm{NO}_{3}\right)_{2} \mathbf{3}$} & $73.22(5)$ & $91.20(8)$ & $94.30(8)$ \\
& $\mathrm{N} 3-\mathrm{M}-\mathrm{O} 6$ & $\mathrm{~N} 13-\mathrm{M}-\mathrm{O} 16$ & \\
{$\left[\mathrm{Cd}(\mathrm{emizco})_{2} \mathrm{Br}_{2}\right] \mathbf{4}$} & $66.58(9)$ & $68.11(9)$ & - \\
\hline
\end{tabular}




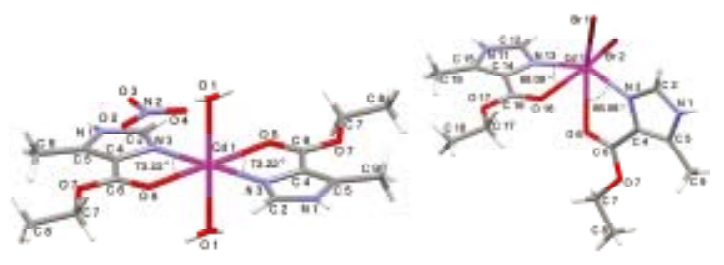

Fig. 4. Chelate angles in the cadmium(II) compounds 3 and $\mathbf{4}$.

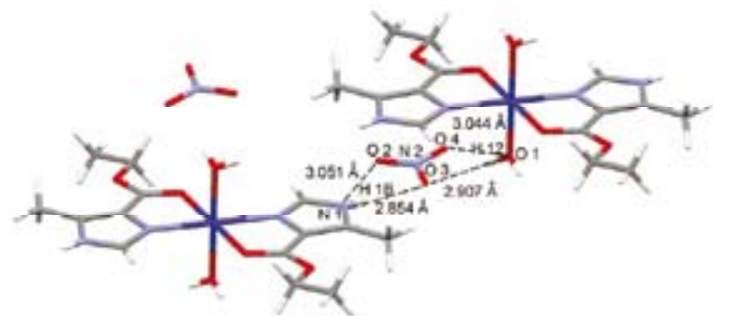

Fig. 5. Intermolecular hydrogen bonding between the nitrate ions and compound $\mathbf{1}$.

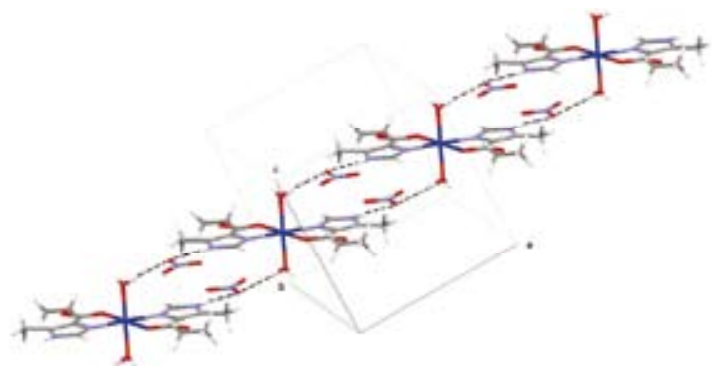

Fig. 6. $2 \mathrm{D}$ arrangement in the ab plane, in $\left[\mathrm{Co}(\text { emizco })_{2}\left(\mathrm{H}_{2} \mathrm{O}\right)_{2}\right]\left(\mathrm{NO}_{3}\right)_{2}$ 1 .

Table 4. Intermolecular hydrogen bond lengths $(\AA)$ of transoctahedral 1- 3 compounds (heavy atoms distances).

\begin{tabular}{cccc}
\hline Compound & $\mathrm{N} 1 \cdots \mathrm{O} 2$ & $\mathrm{O} 1 \cdots \mathrm{O} 3$ & $\mathrm{~N} 1 \cdots \mathrm{O} 3$ \\
\hline$\left[\mathrm{Co}(\text { emizco })_{2}\left(\mathrm{H}_{2} \mathrm{O}\right)_{2}\right]\left(\mathrm{NO}_{3}\right)_{2} \mathbf{1}$ & $3.051(2)$ & $2.907(3)$ & $2.854(2)$ \\
{$\left[\mathrm{Ni}(\mathrm{emizco})_{2}\left(\mathrm{H}_{2} \mathrm{O}\right)_{2}\right]\left(\mathrm{NO}_{3}\right)_{2} \mathbf{2}$} & $2.997(4)$ & $2.897(4)$ & $2.848(3)$ \\
{$\left[\mathrm{Cd}(\mathrm{emizco})_{2}\left(\mathrm{H}_{2} \mathrm{O}\right)_{2}\right]\left(\mathrm{NO}_{3}\right)_{2} \mathbf{3}$} & $3.073(3)$ & $2.986(3)$ & $2.794(3)$ \\
\hline
\end{tabular}

compound 1. The $\mathrm{NH}$ of the imidazolic rings form bifurcated hydrogen bonds with the nitrate ion, N1-H1B $\cdots \mathrm{O} 2 \mathrm{~N} 2(\mathrm{~N} 1 \cdots \mathrm{O} 2$

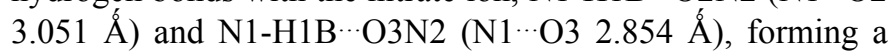
chain, that grows in the a axis direction. Additionally, one coordinated water molecule forms bifurcated hydrogen bonds with the ionic nitrate, $\mathrm{O} 1 \cdots \mathrm{O} 3 \mathrm{~N} 2,\left(2.907 \AA\right.$, $\left.172.85^{\circ}\right)$ and $\mathrm{O} 1 \cdots \mathrm{O} 4-$ N2 (3.044 ̊́, $\left.134.91^{\circ}\right)$, Figure 5.

In tables 4 and 5 are included the intermolecular hydrogen bond lengths and angles for the nitrate trans compounds.

A 3D supramolecular structure is built up by parallel planes, linked by hydrogen bonds between the axial acua ligands and the nitrate ions, Figure 7.

\section{Cis-octahedral compound 4}

In this compound, there are two types of intermolecular interactions: hydrogen bonding and $\pi$ stacking. The intermolecular hydrogen bonds are formed between N1-H of imidazole ring and the $\mathrm{Br} 2$ of a neighbouring molecule, which is shorter than the sum of van der Waals radii of $\mathrm{Br}$ and $\mathrm{N}$ atoms $\left(\Sigma_{\mathrm{rvw}} \mathrm{Br}-\mathrm{N}\right.$ : $3.51 \AA$ ) [29]. In Figure 8 is shown the $\pi$ stacking and hydrogen bonding, which extend the crystal lattice in the bc crystallographic plane, stabilizing a 2D supramolecular arrangement. Similar interactions were found in the analogous copper(II) compound [23].

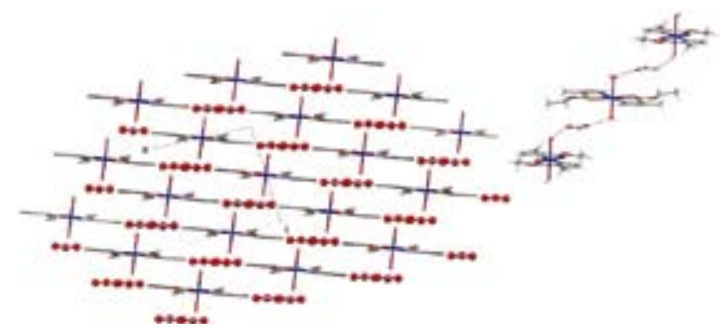

Fig. 7. 3D supramolecular arrangement in compounds 1-3.

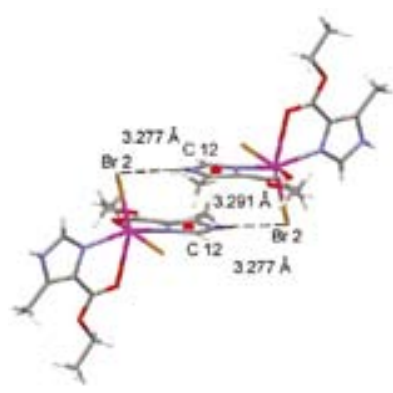

(a)

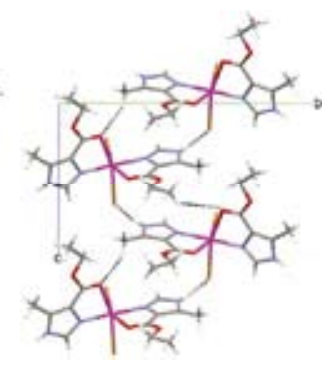

(b)
Fig. 8. (a) Hydrogen bonding and $\pi$ stacking in compound 4; (b) 2D supramolecular arrangement in the bc plane.

Table 5. Intermolecular hydrogen bond angles of trans-octahedral compounds.

\begin{tabular}{llll}
\hline Compound & $\mathrm{N} 1-\mathrm{H} 1 \mathrm{~B} \cdots \mathrm{O} 2$ & $\mathrm{O} 1-\mathrm{H} 12 \cdots \mathrm{O} 4$ & $\mathrm{~N} 1-\mathrm{H} 1 \mathrm{~B} \cdots \mathrm{O} 3$ \\
\hline$\left[\mathrm{Co}(\text { emizco })_{2}\left(\mathrm{H}_{2} \mathrm{O}\right)_{2}\right]\left(\mathrm{NO}_{3}\right)_{2} \mathbf{1}$ & $133.47^{\circ}$ & $172.85^{\circ}$ & $172.72^{\circ}$ \\
{$\left[\mathrm{Ni}(\mathrm{emizco})_{2}\left(\mathrm{H}_{2} \mathrm{O}\right)_{2}\right]\left(\mathrm{NO}_{3}\right)_{2} \mathbf{2}$} & $162.00^{\circ}$ & $178.61^{\circ}$ & $162.00^{\circ}$ \\
{$\left[\mathrm{Cd}(\mathrm{emizco})_{2}\left(\mathrm{H}_{2} \mathrm{O}\right)_{2}\right]\left(\mathrm{NO}_{3}\right)_{2} \mathbf{3}$} & $130.76^{\circ}$ & $150.86^{\circ}$ & $172.22^{\circ}$ \\
\hline
\end{tabular}




\section{Concluding remarks}

All trans-octahedral nitrate compounds stabilized a 3D supramolecular arrangement via hydrogen bonding, between the nitrate anions, the $\mathrm{N}-\mathrm{H}$ from the ligand and the coordinated water molecules. The cis-octahedral halide complex forms a 2D pleated sheet arrangement, by intermolecular $\pi$ stacking and halide-hydrogen bonding. A similar behavior was observed previously for similar nitrate and halide copper(II) compounds, which implies that an anion directed assembly allows the formation of $2 \mathrm{D}$ or $3 \mathrm{D}$ supramolecular structures.

\section{Experimental}

\section{Reagents}

Emizco, metal salts: $\mathrm{CdBr}_{2}, \mathrm{Co}\left(\mathrm{NO}_{3}\right)_{2} \cdot 6 \mathrm{H}_{2} \mathrm{O}, \mathrm{Ni}\left(\mathrm{NO}_{3}\right)_{2} \cdot 6 \mathrm{H}_{2} \mathrm{O}$, $\mathrm{Cd}\left(\mathrm{NO}_{3}\right)_{2}$, and solvents were purchased from Aldrich Chem., Merck and J.T. Baker and were used as received.

\section{Spectroscopic measurements}

IR spectra in the range $4000-400 \mathrm{~cm}^{-1}$ were recorded in $\mathrm{KBr}$ pellets (Perkin Elmer FTIR 1605). Electronic spectra of powdered crystalline samples were measured by the diffuse reflectance method on a CARY -5000 Varian spectrometer, over the range 250-2000 $\mathrm{nm}\left(40,000-5,000 \mathrm{~cm}^{-1}\right)$. Elemental analyses were carried out with a Fisons EA 1108 analyzer (CHNS-O) using a cystine standard. Magnetic susceptibility measurements at room temperature of powdered samples were recorded on a Johnson-Matthey type MSB model MK II 13094-3002, using the Gouy method at a temperature of $297+/-2 \mathrm{~K}$.

\section{Crystallography}

Suitable single crystals of compounds 14 were mounted on a glass fiber. Data were colleted at 293 K. Crystal data, data collection and structure refinement details are given in Table 6. All data were measured using standard procedures on a Oxford Diffraction Gemini " $A$ " instrument with CCD area detector using graphitemonochromated Mo K $\alpha$ radiation at $293 \mathrm{~K}$. Intensities were measured using $\varphi+\omega$ scans. A summary of data collection and refinements is given in Table 6. All structures were solved using direct methods, using SHELX97 program [30] and the refinement (based on $F^{2}$ of all data) was performed by fullmatrix least squares techniques with SHELX97 program [30]. All non hydrogen atoms were refined anisotropically. For all compounds, all non aromatic hydrogen atoms were found in the difference map and their positions refined, whereas all the aromatic hydrogen atoms were localized in the difference map and allowed to ride on their respective atoms.

\section{Synthesis of coordination compounds: general procedure}

Coordination compounds were prepared in all cases using methanol as solvent and employing a 2:1 (ligand: $\mathrm{M}^{2+}$ ) ratio for the cobalt(II) and nickel(II) compounds, and a 1:1 ratio for the cadmium(II) compounds. The emizco ligand was dissolved in $5 \mathrm{~mL}$ of hot methanol, and the metallic salts were dissolved separately in $10 \mathrm{~mL}$ of hot methanol. The metal salt solution was added to the ligand solution and refluxed, after that the solution was allowed to stand at RT. The resulting crystals were washed with methanol and dried in vacuo.

$\left[\mathrm{Co}(\text { emizco })_{2}\left(\mathrm{H}_{2} \mathrm{O}\right)_{2}\right]\left(\mathrm{NO}_{3}\right)_{2}$ (1)

Cobalt(II) nitrate hexahydrate $(0.580 \mathrm{~g}, 2 \mathrm{mmol})$ was dissolved in hot methanol $(10 \mathrm{~mL})$ and added to a solution of emizco $(0.154 \mathrm{~g}, 1 \mathrm{mmol})$ in hot methanol $(5 \mathrm{~mL})$. The red solution was refluxed for $6 \mathrm{~h}$ and then allowed to stand for 4 weeks. The resulting red crystals were filtered off, washed with methanol and dried in vacuo. Yield: $99.43 \%$.

Molar conductivity $\left(\mathrm{H}_{2} \mathrm{O}\right):[\mu \mathrm{S} / \mathrm{cm}] 257$. IR $v_{\max }\left[\mathrm{cm}^{-1}\right]$ $1678(\mathrm{C}=\mathrm{O}), 1509(\mathrm{C}=\mathrm{N}), 1316\left(\mathrm{COO}_{\mathrm{as}}\right), 1214\left(\mathrm{COO}_{\mathrm{s}}\right), 1384$ $\left(\mathrm{NO}_{3}\right)$. Anal. Found: C, 31.46; H, 4.69; N, 15.88\%. Calcd. for $\mathrm{C}_{14} \mathrm{H}_{24} \mathrm{CoN}_{6} \mathrm{O}_{12}: \mathrm{C}, 31.88 ; \mathrm{H}, 4.58 ; \mathrm{N}, 15.93 \%$.

\section{$\left.\left[\mathrm{Ni}(\text { emizco })_{2}\left(\mathrm{H}_{2} \mathrm{O}\right)_{2}\right]\left(\mathrm{NO}_{3}\right)_{2} \cdot \mathbf{2}\right)$}

Nickel(II) nitrate hexahydrate $(0.290 \mathrm{~g}, 1 \mathrm{mmol})$ was dissolved in hot methanol $(10 \mathrm{~mL})$ and added to a solution of emizco $(0.308 \mathrm{~g}, 2 \mathrm{mmol})$ in hot methanol $(5 \mathrm{~mL})$. The green solution was refluxed for $6 \mathrm{~h}$ and then allowed to stand for 5 weeks. The resulting lime green crystals were filtered off, washed with methanol and dried in vacuo. Yield: $30.13 \%$. Molar conductivity $\left(\mathrm{H}_{2} \mathrm{O}\right):[\mu \mathrm{S} / \mathrm{cm}] 222$. IR $v_{\max }\left[\mathrm{cm}^{-1}\right] 1644(\mathrm{C}=\mathrm{O}), 1528$ $(\mathrm{C}=\mathrm{N}), 1217\left(\mathrm{COO}_{\mathrm{s}}\right), 1384\left(\mathrm{NO}_{3}\right)$. Anal. Found: $\mathrm{C}, 31.63 ; \mathrm{H}$, $4.65 ; \mathrm{N}, 16.22 \%$. Calcd. for $\mathrm{C}_{14} \mathrm{H}_{24} \mathrm{NiN}_{6} \mathrm{O}_{12}$ : C, 31.90; H, 4.59; N, $15.94 \%$.

$\left[\mathrm{Cd}(\text { emizco })_{2}\left(\mathrm{H}_{2} \mathrm{O}\right)_{2}\right]\left(\mathrm{NO}_{3}\right)_{2}$ (3)

Cadmium(II) nitrate $(0.236 \mathrm{~g}, 1 \mathrm{mmol})$ was dissolved in hot methanol $(10 \mathrm{~mL})$ and added to a solution of emizco $(0.154$ $\mathrm{g}, 1 \mathrm{mmol})$ in hot methanol $(5 \mathrm{~mL})$. The colorless solution was refluxed for $6 \mathrm{~h}$ and then allowed to stand for 4 weeks. The resulting colorless crystals were filtered off, washed with methanol and dried in vacuo. Yield: $32.38 \%$. Molar conductivity (DMSO): $[\mu \mathrm{S} / \mathrm{cm}]$ 78.8. IR $v_{\max }\left[\mathrm{cm}^{-1}\right] 1655(\mathrm{C}=\mathrm{O}), 1525$ $(\mathrm{C}=\mathrm{N}), 1335\left(\mathrm{COO}_{\mathrm{as}}\right), 1163\left(\mathrm{COO}_{\mathrm{s}}\right), 1384\left(\mathrm{NO}_{3}\right)$. Anal. Found: C, 28.75; H, 4.30; N, 14.12\%. Calcd. for $\mathrm{C}_{14} \mathrm{H}_{24} \mathrm{CdN}_{6} \mathrm{O}_{12}: \mathrm{C}$, $28.95 ; \mathrm{H}, 4.16 ; \mathrm{N}, 14.47 \%$.

\section{$4\left[\mathrm{Cd}(\mathrm{emizco})_{2} \mathrm{Br}_{2}\right](\mathbf{4})$}

Cadmium(II) bromide (0.272 $\mathrm{g}, 1 \mathrm{mmol})$ was dissolved in hot methanol $(10 \mathrm{~mL})$ and added to a solution of emizco $(0.154 \mathrm{~g}$, $1 \mathrm{mmol})$ in hot methanol $(5 \mathrm{~mL})$. The colorless solution was refluxed for $6 \mathrm{~h}$ and then allowed to stand for 4 weeks. The resulting colorless crystals were filtered off, washed with methanol and dried in vacuo. Yield: $21.5 \%$. IR $v_{\max }\left[\mathrm{cm}^{-1}\right] 1679(\mathrm{C}=\mathrm{O})$, $1522(\mathrm{C}=\mathrm{N}), 1324\left(\mathrm{COO}_{\mathrm{as}}\right), 1206\left(\mathrm{COO}_{\mathrm{s}}\right)$. Anal. Found: $\mathrm{C}$, 28.80; H, 3.67; N, 9.40\%. Calcd. for $\mathrm{C}_{14} \mathrm{H}_{20} \mathrm{CdN}_{4} \mathrm{O}_{4} \mathrm{Br}_{2}: \mathrm{C}$, 28.96; H, 3.47; N, 9.65\%. 
Table 6. Crystal data, data collection and refinement details for 1, 2, 3 and 4.

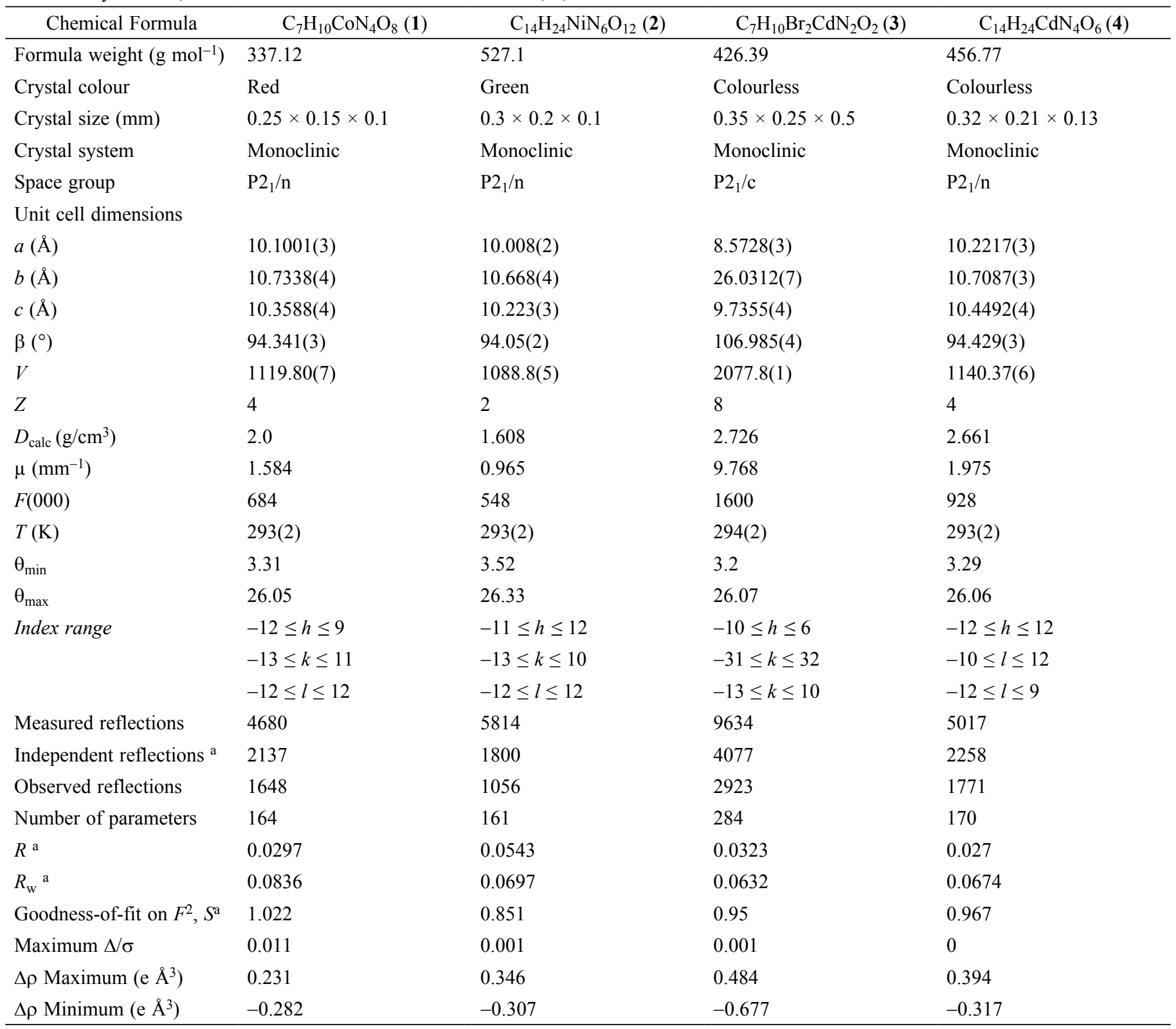

${ }^{\text {a }} R_{\text {int }}, R_{1}, w R_{2}$ and $S$ are defined as follows:

\section{Supplementary material}

Supplementary crystallographic data for this paper have been deposited with the CCDC: 810798 to 810801 . These data can be obtained free of charge via www.ccdc.cam.ac.uk/data_request/ cif, by emailing data_request@ccdc.cam.ac.uk, or by contacting The Cambridge Crystallographic Data Centre, 12, Union Road, Cambridge CB2 1EZ, UK; fax: +44 1223336033.

\section{Acknowledgements}

This work was supported by the project DGAPA-UNAM IN212210 We acknowledge R.P. Fierro for technical support.

\section{References}

1. Gilman, A.; Goodman Gilman, L.S.; Rall, T.W.; Murad, F., in: Goodman and Gilman's The Pharmacological Basics of Therapeutics. $7^{\text {th }}$ Ed., Mc-Graw Hill, New Jersey, 1986, pp. 11661168.

2. Sunkyung, L.; Kyu, Y. Y.; Sung, J. Y.; Byung, H. L.; Sung-Eun, Y. Bioorg. Med. Chem. Lett. 2009, 19, 1329-1331.

3. Abhishek, K. J.; Ravichandranb, V; Madhvi, S; Agrawala, R. K. J. Trop. Med. 2010, 3, 471-474.

4. Castelli, M.; Malagoli, M.; Lupo, L.; Bofia, S.; Paloucci, C.; Zanca, A.; Baggio, G. J. Antimicro. Chemoth. 2000, 46, 541-550.

5. Britzi, M.; Gross, M.; Lavy, E.; Soback, S.; Steinman, A. J. Vet. Pharmacol. Ther. 2010, 33, 511-514.

6. Silvestri, R.; Artico, M.; Marceddu, S. T.; DeMontis, F.; LaColla, P. Bioorg. Med. Chem. Lett. 2000, 10, 253-256. 
7. Hu, J.; McDougald, L. R. Vet. Parasitol. 2004, 121, 233-238.

8. Demirayak, S.; Karaburun, A.C.; Kiraz, N. Eur. J. Med. Chem. 1999, 34, 275-278.

9. Tong, L.; Perez, S.; Goncalves, C.; Alpendurada, F.; Wang, Y.; Barcelo, D. Anal. Bioanal. Chem. 2011, 399, 421-428.

10. Weijun, L. Chinese Patent, CODEN: CNXXEV CN 101884642 A 20101117 2010. Appl.: CN 2010-10240918 20100730. Priority: CN 2010-10240918 20100730. CAN 153:651461 AN 2010:1447071.

11. Macdonald, F. M.; Sadler, P.S. Polyhedron 1991, 10, 14431448.

12. Macdonald, F. M., Sadler P.S. Magn. Reson. Chem. 1991, 29, S52-59

13. Rochon, B. D.; Melanson R.; Farrel, N. Acta Cryst. 1993, C49, 1706-1715.

14. Dyson, T. M.; Morrison, E. C.; Tocher, D.A.; Dale, L. D.; Edwards, D. I. Inorg. Chim. Acta 1990, 169, 127-131.

15. Roy, M. B.; Mandal, P. C.; Bhattacharyya, S. N. Int. J. Radiat. Biol. 1996, 69, 471-480.

16. Roy, M. B.; Mandal, P. C.; Bhattacharyya, S. N. J. Radioanal. Nucl. Chem.1995, 191, 337-348.

17. Roy, M. B.; Mandal, P. C.; Bhattacharyya, S.N. J. Chem. Soc., Dalton Trans. 1993, 2485-2490.

18. Roy, M. B.; Mandal, P. C.; Bhattacharyya, S.N. Bull. Chem. Soc. Jpn. 1990, 63, 2975-2980.

19. Rachna, K.; Singh, P. Asian J. Chem. 2000, 12, 23-26.
20. Galván-Tejada, N.; Bernès, S.; Castillo-Blum, S. E.; Nöth, H.; Vicente, R.; Barba-Behrens, N. J. Inorg. Biochem. 2002, 91, 339348.

21. Gant, T. G.; Sarshar, S. US patent CODEN:USXXCO US 20100113478 A1 2010.

22. Heim-Riether, A.; Healy, J. J. Org. Chem. 2005, 70 (18), 73317337.

23. Montes-Ayala, J.; Escartín-Guzmán, C.; Castillo-Blum, S. E.; Rodríguez-Hernández, E. O.; Bernès, S.; Rosales-Hoz, Ma. J.; BarbaBehrens, N. J. Inorg. Biochem. 2005, 99, 1676-1684.

24. King-Díaz, B.; Barba-Behrens, N.; Montes-Ayala, J.; CastilloBlum, S. E.; Escartín-Guzmán, C.; Iglesias-Prieto, R.; LotinaHennsen, B. Z. Naturforsch 1998, 53C, 987-994.

25. King-Díaz, B.; Montes-Ayala, J.; Escartín-Guzmán, C.; CastilloBlum, S. E.; Iglesias-Prieto, R.; Lotina-Hennsen, B.; Barba-Behrens, N. Bioinorg. Chem. \& Appl. 2005, 3(1-2), 93-108.

26. Lever, A.B.P., in: Inorganic Electronic Spectroscopy, $2^{\text {nd }}$ Ed. Elsevier, New York, 1986, pp. 507-511.

27. Acuña-Cueva, E. R.; Faure, R.; Illán-Cabeza, N. A.; Jiménez-Pulido, S. B.; Moreno-Carretero, M. N.; Quirós-Olozábal, M. Polyhedron 2002, 21, 19611968

28. Acuña-Cueva, E. R.; Faure, R.; Illán-Cabeza, N. A.; Jiménez-Pulido, S. B.; Moreno-Carretero, M. N.; Quirós-Olozábal, M. Inorg. Chim. Acta 2003, 342, 209218.

29. Batsanov, S. S. Inorganic Materials, 2001, 37, 871885.

30. Sheldrick, G. M. Acta Crystallogr., 2008 Sect. A 64 112-122. 